\title{
Clinical Implications of Girdin Protein Expression in Glioma
}

\author{
Liwei Zhao, ${ }^{1}$ Shuyin $\mathrm{Ma}^{2}{ }^{2}$ Qing Liu, ${ }^{3}$ and Peng Liang ${ }^{3}$ \\ ${ }^{1}$ Department of Neurosurgery, The First Affiliated Hospital of Harbin Medical University, Harbin, Heilongjiang 150001, China \\ ${ }^{2}$ Department of Rehabilitation, The First Affiliated Hospital of Harbin Medical University, Harbin, Heilongjiang 150001, China \\ ${ }^{3}$ Department of Neurosurgery, The Third Affiliated Hospital of Harbin Medical University, Harbin, Heilongjiang 150040, China
}

Correspondence should be addressed to Peng Liang; liangpengharbin@163.com

Received 14 July 2013; Accepted 28 August 2013

Academic Editors: W. Hall, A. Percesepe, and B. Schaller

Copyright (C) 2013 Liwei Zhao et al. This is an open access article distributed under the Creative Commons Attribution License, which permits unrestricted use, distribution, and reproduction in any medium, provided the original work is properly cited.

\begin{abstract}
Objective. To investigate the expression status of Girdin in glioma and the relationship between Girdin expression and the biological behavior of glioma. Materials and methods. The expression status of Girdin in glioma from 560 cases was evaluated by RT-PCR, Western Blot and immunohistochemistry. The relationship between Girdin expression and clinic-pathological parameters as well as prognosis was also studied. Results. The expression of Girdin in high grade glioma was significantly higher than low grade glioma. After universal analysis, the expression of Girdin protein is closely related to KPS score, extent of resection, Ki67 and WHO grade, but it was not related to sex and age. Finally, extent of resection, Ki67 and WHO grade were indentified to be related to the Girdin protein expression in logistic regression. Interestingly, we found that the expression of Girdin is significantly related to the distant metastasis of glioma. After COX regression analysis, KPS score, Extent of resection, Ki67, WHO grade as well as Girdin were observed to be independent prognostic factors. Conclusions. Girdin is differential expressed in the glioma patients and closely related to the biological behavior of Glioma. Finally, Girdin was found to be a strong predictor for the post-operative prognosis.
\end{abstract}

\section{Introduction}

Glioma is a type of tumor that starts in the brain or spine, and the most common site of gliomas is the brain [1]. Glioma make up $\sim 30 \%$ of all brain and central nervous system tumors and $80 \%$ of all malignant brain tumors [2]. Gliomas are further categorized according to their grade, which is determined by pathologic evaluation of the tumor. Low-grade gliomas [WHO grade II] are well differentiated; these are benign and portend a better prognosis for the patient. Highgrade [WHO grade III-IV] gliomas are undifferentiated or anaplastic; these are malignant and carry a worse prognosis [3].

High-grade Gliomas are highly vascular tumors and have a tendency to infiltrate [4]. They have extensive areas of necrosis and hypoxia. Often, tumor growth causes a breakdown of the blood-brain barrier in the vicinity of the tumor. As a rule, high-grade Glioma almost always grow back even after complete surgical excision and so are commonly called recurrent cancer of the brain. On the other hand, lowgrade Gliomas grow slowly, often over many years, and can be waited and followed up closely without treatment unless they grow and cause symptoms [5].

The prognosis for patients with Glioma is generally poor, and it is especially so for older patients. Of 10,000 Americans diagnosed each year with malignant Gliomas, about half are alive one year after diagnose and $25 \%$ after two years [6]. So, how to diagnose and treat carcinoma early becomes of a great need. Glioma is a heterogeneous disease embracing several different phenotypes with consistently different biological characteristics [7]. Finding out a new potential marker for Gliomas and understanding the clinical significance of them and relationships between them would be valuable for current antitumor therapies and the development of novel ones [8].

Currently, studies addressing the function and specific mechanism of Girdin in the biological behavior of Glioma are rare. Moreover, the relationship between Girdin protein expression and clinicopathological features of Glioma is still not clear. In the present study, we investigate the expression status and clinical implications of Girdin protein in Glioma in order to lay a foundation for managing Glioma. 


\section{Materials and Methods}

2.1. Clinical Specimens and Experimental Materials. The paraffin specimens of 560 brain glioma cases were collected from Liaoning Provincial Tumor Hospital and Harbin Medical University from January 2001 to January 2010. These cases were used for testing immunohistochemical protein levels and for the analysis of prognosis. The average age of enrolled patients was $45.21 \pm 6.23$ years (ranging from 35 to 83 years). The study protocol was approved by the Ethics Committee of Harbin Medical University.

2.2. RT-PCR. Total RNA was isolated using Trizole according to manufacture's instruction. cDNAs were synthesized using Revert Aid TM first cDNA synthesis kit (Fermentas). Quantitative real-time PCR was performed using SYBR Green PCR Master Mix on Applied Biosystems 7500 Fast Real-Time PCR System. Primers used in this work were designed using Invitrogen's Oligo Perfec Designer and evaluated with Netc Primer from Premier biosoft [9]. The reaction conditions are: $95^{\circ} \mathrm{C}$ and $5 \mathrm{~min}$, followed by 40 cycles of $94^{\circ} \mathrm{C} 15 \mathrm{~s}$, 55.5 , or $55.2^{\circ} \mathrm{C} 20 \mathrm{~s}$. Melting temperature curve analyses were performed after PCR.

2.3. Western Blot Procedures. Protein concentrations were determined using BCA assay (Santa Cruz Biotech). Equal amounts of total proteins were loaded and separated by SDS-PAGE electrophoresis and transferred onto PVDF membrane. Blots were blocked using 5\% fat-free milk in PBS at $37^{\circ} \mathrm{C}$ for $2 \mathrm{~h}$, followed by $2 \mathrm{PBST}$ washes. Primary antibodies were then added: Girdin antibody (1:500; santa cruz biotechnology, inc) and GAPDH antibody (1:800; santa cruz biotechnology, inc). Blots were incubated with primary antibodies at $4^{\circ} \mathrm{C}$ overnight and then washed four times with PBST before adding secondary antibody. HRP-conjugated anti-rabbit or anti-mouse or anti-goat IgG antibody was used as a secondary antibody and incubated with the blots for $1 \mathrm{~h}$ at room temperature followed by four washes with PBST. Protein bands were visualized with chemiluminescence, and the target protein quantity was determined by normalizing the densities of corresponding bands to those of the loading control bands (GAPDH).

2.4. Immunohistochemistry Procedures. Tumor tissue microarray blocks were freshly cut into $4 \mu \mathrm{m}$ thick sections. Sections were fixed on slides and dried for 12-24 hours at $37^{\circ} \mathrm{C}$. Sections were subsequently deparaffinized in xylene and rehydrated through gradually decreasing concentrations of ethanol to distilled water. After antigen retrieval, sections were incubated for $60 \mathrm{~min}$ with the primary antibody. Following washings with PBS, sections were incubated for $30 \mathrm{~min}$ in the secondary biotinylated antibody (multilink swine anti-goat/mouse/rabbit immunoglobulin; Dako). Following washings, Avidin Biotin Complex (1:1000 dilution; Vector Laboratories) was then applied to the sections for 30-60 min at room temperature. The immunoreactive products were visualized by catalysis of 3, 3-diaminobenzidine (DAB) by horseradish peroxidase in the presence of $\mathrm{H}_{2} \mathrm{O}_{2}$ following

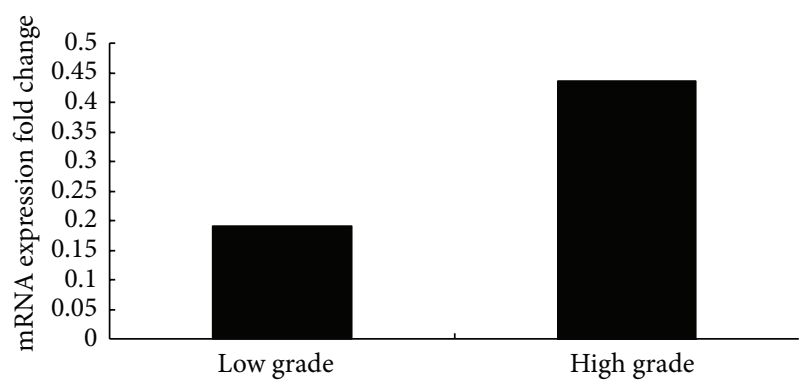

FIGURE 1: RT-PCR analysis showed that Girdin mRNA was upregulated in high-grade Gliomas cancer tissues when compared to lowgrade tumor tissues $(P=0.001)$.

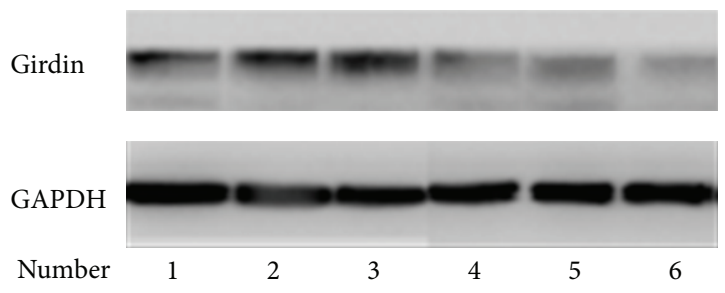

FIGURE 2: Girdin protein was upregulated in high-grade Gliomas cancer tissues when compared to low-grade tumor tissues in western blot analysis $(P=0.01)$.

extensive washing. Sections were then counterstained in Gill's hematoxylin and dehydrated in ascending grades of methanol before clearing in xylene and mounting under a coverslip.

For negative controls, sections were treated with $0.01 \mathrm{~mol} / \mathrm{L}$ PBS instead of primary antibodies; for positive controls, normal breast tissue section staining was positive. The positive cells of Girdin protein were defined as those with clearly brown granules located in the cytoplasm of cells. Two hundred cells from two selected representative fields of each section were counted by two independent observers for the determination of their immunostaining intensity. Staining intensity was initially recorded on a 4-point scale: 0: no staining; 1: light brown; 2: brown; 3: dark brown. The extent of staining also was initially assessed on a 3-point scale: $0:<9 \%$ positive cells; $1: 10 \% \sim 50 \%$ positive cells; $2:>50 \%$ positive cells. According to the above assessment criterion, the immunostaining results were classified into $0 \sim 2$ : low/loss expression of Girdin protein, and 3 6: high expression of Girdin protein.

2.5. Statistical Analysis. All data were analyzed with SPSS statistics software (Version 13.0, Chicago, IL, USA). The relationships between Girdin and other parameters were studied using the chi-square test, Fisher's extract test, or independent $t$-tests. Disease-specific survival was analyzed using the Kaplan-Meier method. The log-rank test was used to analyze differences in survival. Multivariate analysis was performed using the Cox proportional hazards model selected in forward stepwise. A $P$ value of less than 0.05 was considered statistically significant. 


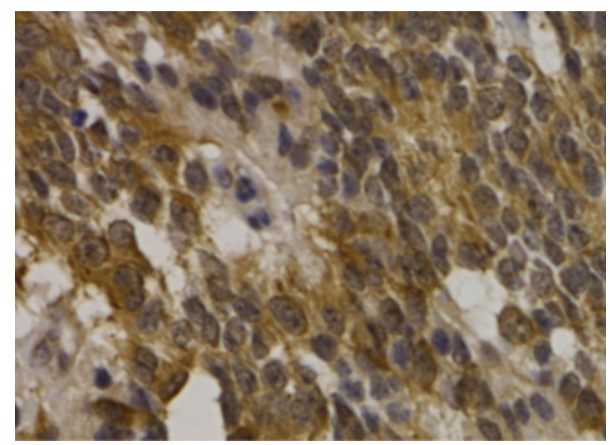

(a)

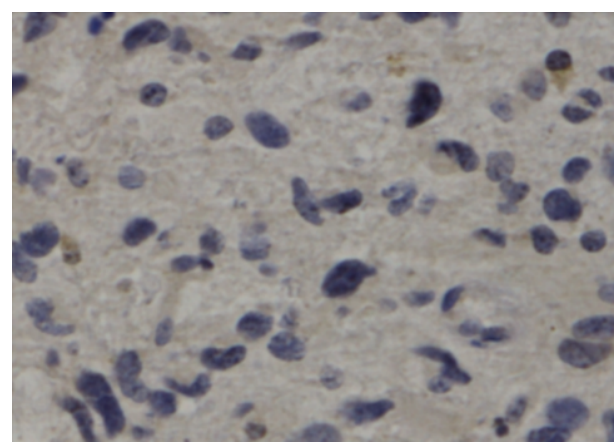

(b)

Figure 3: The expressions of Girdin in Gliomas tissues $(\times 400)$. (a) High-grade gliomas stained with Girdin; (b) Low-grade gliomas stained with Girdin.

\section{Results}

3.1. Girdin Expression in Human Gliomas Tissues at $m R N A$ and Protein Levels. RT-PCR analysis of Girdin mRNA expression in high-grade (WHO III-IV) and low-grade (WHO II) tumor tissues showed that Girdin mRNA was upregulated in high-grade Gliomas cancer tissues when compared to low-grade tumor tissues $(P=0.035)$ (Figure 1$)$. Furthermore, in western blot analysis, the Girdin protein was upregulated in high grade gliomas cancer tissues when compared to low grade tumor tissues $(P=0.01)$ (Figure 2$)$.

\subsection{The Expression of Stem Cell Gene Girdin in Gliomas} Patients and the Relationship between Girdin Expression and Clinic-Pathological Characteristics. It was shown that Girdin was located in the cytoplasm of Glioma cells. In 174 (31.07\%) Glioma patients, differently expressed Girdin protein in immunohistochemistry were observed (Figure 3). After universal analysis, it was found that the expression of Girdin protein is closely related to KPS score, extent of resection, Ki67, and WHO grade $(P=0.002,0.001,0.001$, and 0.035 , resp.), but it was not related to sex and age $(P=0.102$ and 0.225 , resp.) (Table 1). Finally, extent of resection, Ki67, and WHO grade were identified to be related to the Girdin protein expression in logistic regression $(P=0.011,0.002$, and 0.001) (Table 2).

3.3. Prognostic Analysis. After survival analysis, the cases with highly expressed Girdin protein attained a significantly poorer postoperative disease-specific survival than those with high expressed Girdin protein $(P=0.001)$ (Figure 4$)$. In the Cox regression test, KPS, extent of resection, Ki67, WHO grade, and Girdin were observed to be independent prognostic factors $(P=0.050,0.001,0.011,0.001$, and 0.001 , resp.) (Table 3).

\section{Discussion}

Girdin is a novel protein, which is found at the crossroad of $G$ protein signaling and tyrosine kinase receptor signaling [10]. It was also an actin-binding protein identified as a novel
TABLE 1: Relationship between Girdin expression and clinicpathological factors of 560 Gliomas.

\begin{tabular}{lccccc}
\hline Variable & $n$ & \multicolumn{2}{c}{ Girdin $(n(\%))$} & $X^{2}$ & P value \\
\hline Sex & & + & - & & \\
$\quad$ Male & 306 & 104 & 202 & & \\
$\quad$ Female & 254 & 70 & 184 & & \\
$\quad$ Age (years) & & & & 1.470 & 0.225 \\
$\quad \leq 50$ & 320 & 106 & 214 & & \\
$\quad>50$ & 240 & 68 & 172 & & \\
KPS & & & & 9.469 & 0.002 \\
$\quad \leq 80$ & 184 & 73 & 111 & & \\
$\quad>80$ & 376 & 101 & 275 & & \\
Extent of resection & & & & 30.097 & 0.001 \\
$\quad$ Subtotal & 128 & 65 & 63 & & \\
$\quad$ Total & 432 & 109 & 323 & & \\
Ki67 & & & & 42.426 & 0.001 \\
$\quad \quad+$ & 262 & 117 & 145 & & \\
$\quad-$ & 298 & 57 & 241 & & \\
WHO garde & & & & 4.425 & 0.035 \\
$\quad$ I-II & 203 & 52 & 151 & & \\
$\quad$ III-IV & 357 & 122 & 235 & & \\
\hline
\end{tabular}

TABLE 2: Multivariate analysis of the factors related to Girdin expression.

\begin{tabular}{lccc}
\hline Characteristic & $\operatorname{Exp}(B)$ & $95 \%$ CI for $\operatorname{Exp}(B)$ & $P$ value \\
\hline Sex & 0.952 & $0.564-1.607$ & 0.854 \\
Age & 1.538 & $0.828-2.855$ & 0.173 \\
KPS & 1.120 & $0.669-1.876$ & 0.666 \\
Extent of resection & 1.748 & $1.134-2.695$ & 0.011 \\
Ki67 & 0.263 & $0.111-0.622$ & 0.002 \\
WHO grade & 2.563 & $1.585-3.161$ & 0.001 \\
Constant & 0.022 & & \\
\hline
\end{tabular}

CI: confidence interval.

substrate of Akt, and it regulates the sprouting of axons and the migration of neural progenitor cells during early postnatal-stage neurogenesis in the hippocampus. When the epidermal growth factor receptor signaling is activated, 

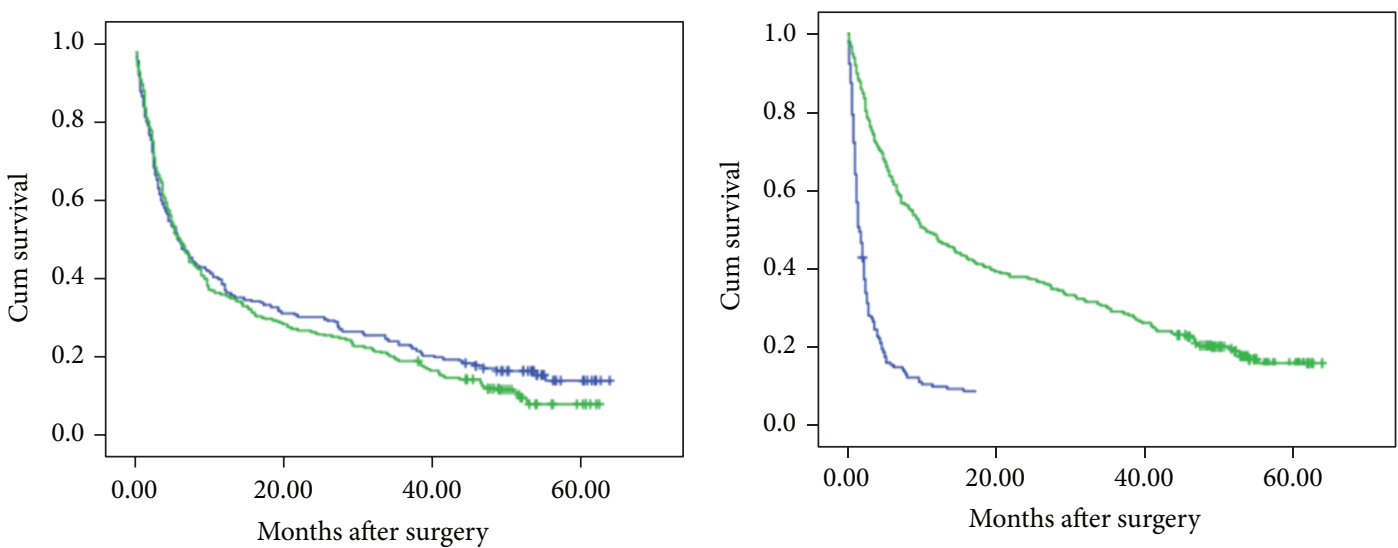

KPS

$\longrightarrow>80$

Extent of resection

— Total

— Subtotal

(a)

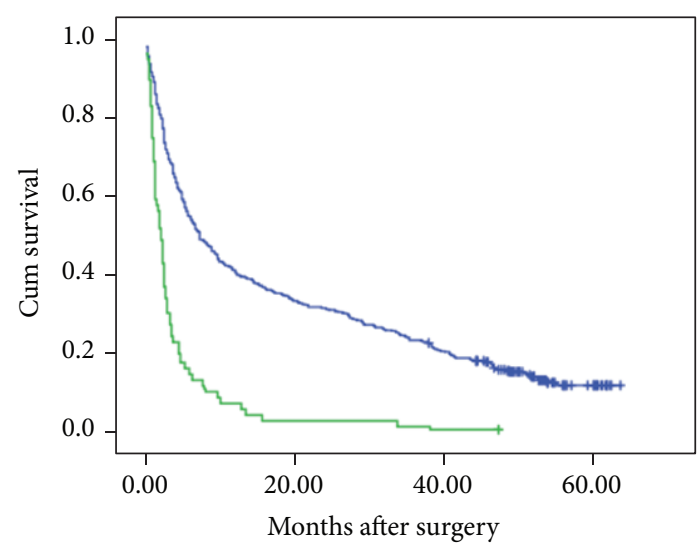

(b)

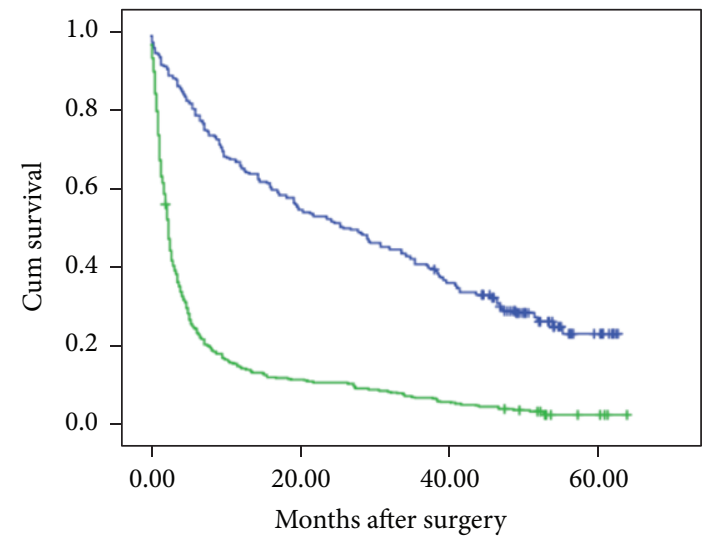

Ki67

WHO garde

$++$

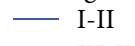

— III-IV

(c)

(d)

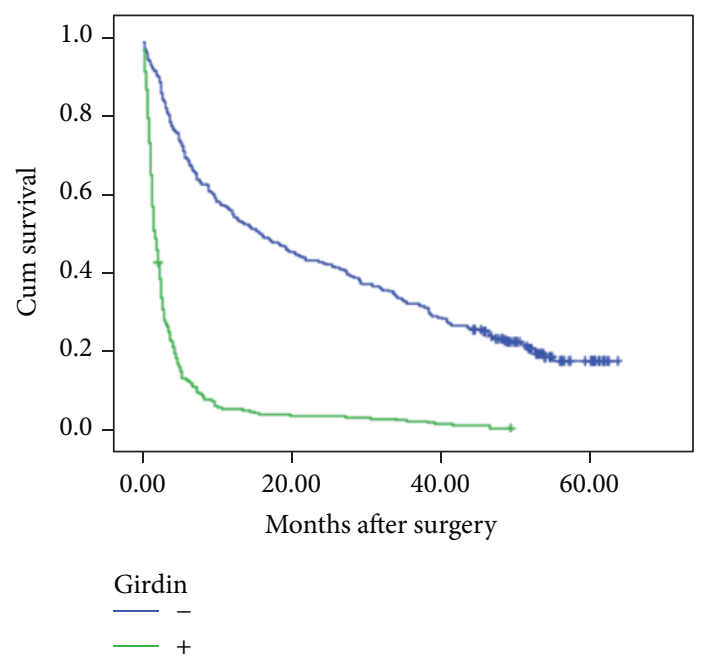

(e)

FIGURE 4: The survival analysis showed that KPS score (a), extent of resection (b), Ki67 (c), WHO grade (d), and Girdin (e) were observed to be independent prognostic factors $(P=0.044,0.010,0.002,0.001$, and 0.001 , resp. $)$. 
TABLE 3: Cox model regression analysis of prognostic factors for the gliomas.

\begin{tabular}{lccc}
\hline Varies & OR & $95 \%$ CI for OR & $P$ value \\
\hline Sex & 1.182 & $0.996-1.403$ & 0.056 \\
Age & 0.938 & $0.751-1.170$ & 0.569 \\
KPS & 0.726 & $0.580-0.909$ & 0.050 \\
Extent of resection & 2.159 & $1.521-3.065$ & 0.001 \\
Ki67 & 1.805 & $0.681-0.951$ & 0.011 \\
WHO grade & 1.894 & $1.496-2.816$ & 0.001 \\
GIRDIN & 2.295 & $1.870-2.816$ & 0.001 \\
\hline
\end{tabular}

Girdin is activated directly by Akt [11]. Recently, LópezSánchez et al. found that a Girdin-G $\alpha$ i molecular complex binds to the epidermal growth factor receptor and determines whether cells migrate or proliferate [12]. They also suggested that the expression of Girdin predicts patient survival in colon cancer and that Girdin may serve as a useful adjunct to traditional staging strategies in colorectal carcinoma [12]. Gliomas are the most common and aggressive type of brain tumor. Gliomas usually show hyperactivation of the PI3K-Akt pathway, a protumorigenic signaling cascade that contributes to pathogenesis [13]. Recently, Natsume et al. observed that stable Girdin knockdown in isolated Gliomas stem cells resulted in decreased expression of stem cell markers, including CD133, induced multilineage neural differentiation, and inhibited in vitro cell motility, ex vivo invasion, sphere-forming capacity, and in vivo tumor formation [14, 15]. They concluded that Girdin is required for Gliomasinitiating stem cells to sustain the stemness and invasive properties. However, there exists no studies investigating the expression status of Girdin protein in Gliomas, and its relationship to the biological behavior of Gliomas is still unclear. Furthermore, there is no study that addressed Girdin expression in Gliomas and the relationship between it and the prognosis of Gliomas.

The prognosis of Glioma was worse, though the patients received operations combined with radiotherapy and chemotherapy treatment [16]. Research priorities of the next 10 years will be committed to basic and translational medicine. The new treatment methods including the development of new drugs to block cell proliferation signaling pathway are to overcome the drug resistance of chemotherapy. In a study, Girdin is required for Glioma stem cells to sustain the stemness and invasive properties [17]. Therefore, Girdin maybe a potential new target for the treatment of Glioma.

In the study, we evaluated the expression status of Girdin in Glioma and observed that Girdin was significantly higher in Glioma tissues compared to paracancer tissues. After universal analysis, it was found that Girdin protein is closely related to KPS score, extent of resection, Ki67, and WHO grade. However, only extent of resection, Ki67, and WHO grade were identified to be related to the Girdin expression in multiple regression. Finally, Girdin was observed to be independent prognostic factor for glioma.

\section{Conclusion}

The expression of Girdin is closely related to the biological behavior of brain glioma. It is an independent prognostic factor in glioma, which can provide the basis for clinical treatment of brain glioma.

\section{Acknowledgments}

This research is supported by the Natural Scientific Foundation Program of Heilongjiang Province (D: 201104) and Yuweihan Excellent Young Scientist Foundation of Harbin Medical University.

\section{References}

[1] M. Toda, "Glioma stem cells and immunotherapy for the treatment of malignant gliomas," ISRN Oncology, vol. 2013, Article ID 673793, 13 pages, 2013.

[2] P. De Bonis, G. Lofrese, C. Anile, A. Pompucci, V. Vigo, and A. Mangiola, "Radioimmunotherapy for high-grade glioma," Immunotherapy, vol. 5, no. 6, pp. 647-659, 2013.

[3] P. J. Vlachostergios, I. A. Voutsadakis, and C. N. Papandreou, "The role of ubiquitin-proteasome system in glioma survival and growth," Growth Factors, vol. 31, no. 3, pp. 106-113, 2013.

[4] M. G. Hart, R. Grant, R. Garside, G. Rogers, M. Somerville, and K. Stein, "Temozolomide for high grade glioma," Cochrane Database of Systematic Reviews, no. 4, Article ID CD007415, 2008.

[5] A. A. Nadaj-Pakleza, M. Dorobek, K. Nestorowicz, B. Ryniewicz, E. Szmidt-Sałkowska, and A. M. Kamińska, "Reoperations of patients with low-grade gliomas in eloquent or near eloquent brain areas," Neurologia i Neurochirurgia Polska, vol. 47, no. 3, pp. 214-222, 2013.

[6] H. Kim, S. H. Choi, J. H. Kim et al., "Gliomas:application of cumulative histogram analysis of normalized cerebral blood volume on 3 T MRI to tumor grading," PLOS ONE, vol. 8, no. 5, Article ID e63462, 2013.

[7] H. W. Xu, Y. J. Huang, Z. Y. Xie et al., "The expression of cytoglobin as a prognostic factor in gliomas: a retrospective analysis of 88 patients," BMC Cancer, vol. 13, article 247, 2013.

[8] W. Wu, Y. Tian, H. Wan, Y. Song, J. Li, and L. Zhang, "The expressions of Wnt/ $\beta$-catenin pathway-related components in brainstem gliomas," Canadian Journal of Neurological Sciences, vol. 40, no. 3, pp. 355-360, 2013.

[9] P. Ghosh, A. O. Beas, S. J. Bornheimer et al., "A G Gi-GIV molecular complex binds epidermal growth factor receptor and determines whether cells migrate or proliferate," Molecular Biology of the Cell, vol. 21, no. 13, pp. 2338-2354, 2010.

[10] A. Enomoto, J. Ping, and M. Takahashi, "Girdin, a novel actinbinding protein, and its family of proteins possess versatile functions in the Akt and Wnt signaling pathways," Annals of the New York Academy of Sciences, vol. 1086, pp. 169-184, 2006.

[11] F. Jin, C. Liu, Y. Guo, H. Chen, and Y. Wu, "Clinical implications of Girdin and PI3K protein expression in breast cancer," Oncology Letters, vol. 5, no. 5, pp. 1549-1553, 2013.

[12] I. López-Sánchez, M. Garcia-Marcos, Y. Mittal, N. Aznar, M. G. Farquhar, and P. Ghosh, "Protein kinase C-theta (PKC $\theta)$ phosphorylates and inhibits the guanine exchange factor, GIV/Girdin," Proceedings of the National Academy of Sciences 
of the United States of America, vol. 110, no. 14, pp. 5510-5515, 2013.

[13] P. Millet, C. Granotier, O. Etienne, and F. D. Boussin, "Radiation-induced upregulation of telomerase activity escapes PI3kinase inhibition in two malignant glioma cell lines," International Journal of Oncology, vol. 43, no. 2, pp. 375-382, 2013.

[14] A. Natsume, S. Kinjo, K. Yuki et al., "Glioma-initiating cells and molecular pathology: implications for therapy," Brain Tumor Pathology, vol. 28, no. 1, pp. 1-12, 2011.

[15] A. Natsume, T. Kato, S. Kinjo et al., "Girdin maintains the stemness of glioblastoma stem cells," Oncogene, vol. 31, no. 22, pp. 2715-2724, 2012.

[16] N. Y. Hernández-Pedro, E. Rangel-López, R. MagañaMaldonado et al., "Application of nanoparticles on diagnosis and therapy in gliomas," BioMed Research International, vol. 2013, Article ID 351031, 20 pages, 2013.

[17] A. Natsume, T. Kato, S. Kinjo et al., "Girdin maintains the stemness of glioblastoma stem cells," Oncogene, vol. 31, no. 22, pp. 2715-24, 2012. 


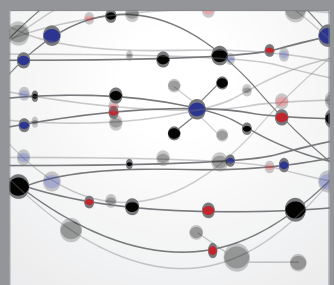

The Scientific World Journal
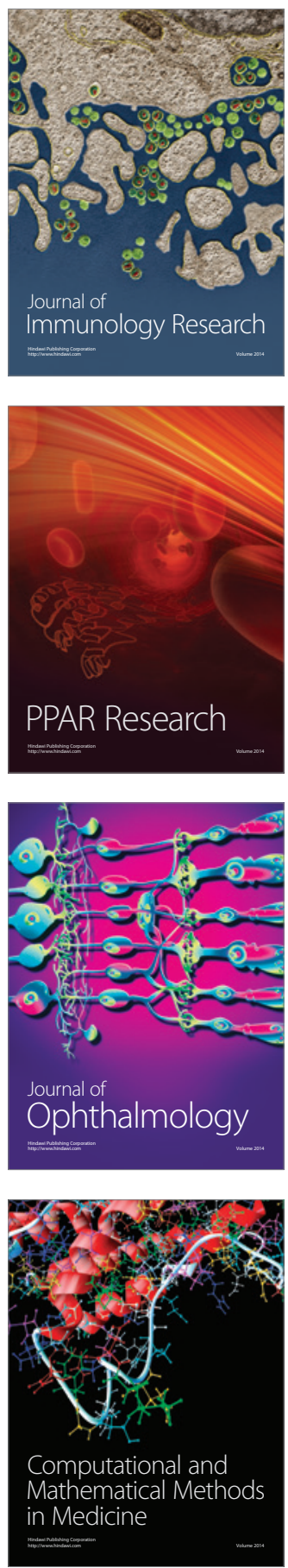

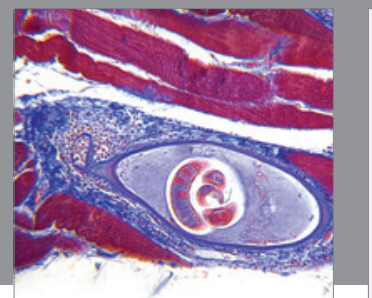

Gastroenterology

Research and Practice
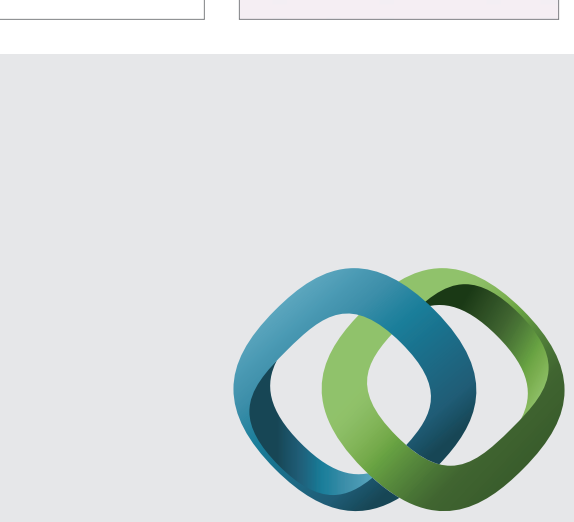

\section{Hindawi}

Submit your manuscripts at

http://www.hindawi.com
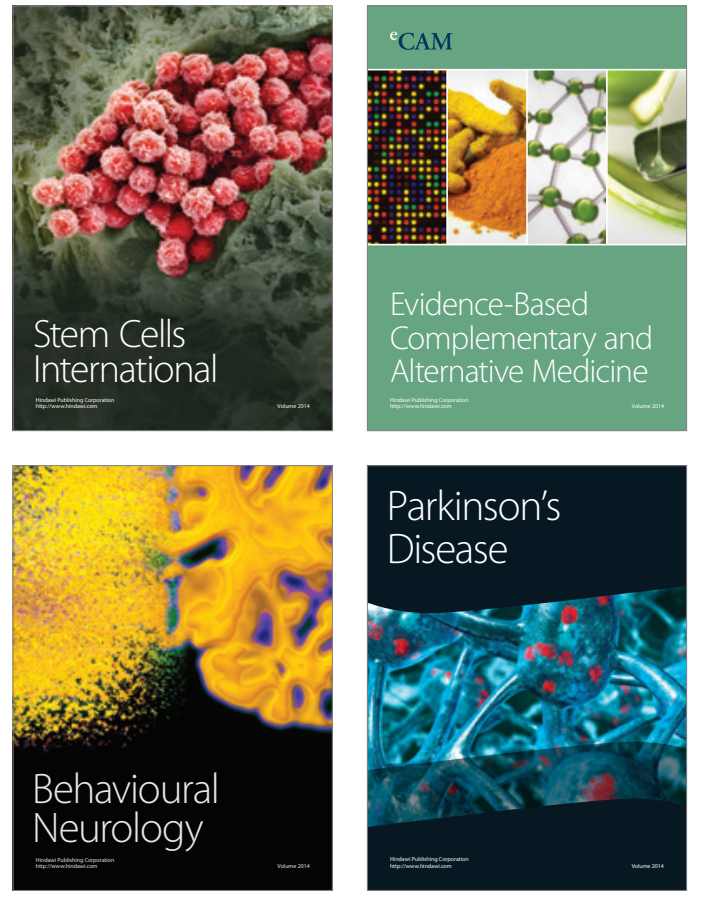
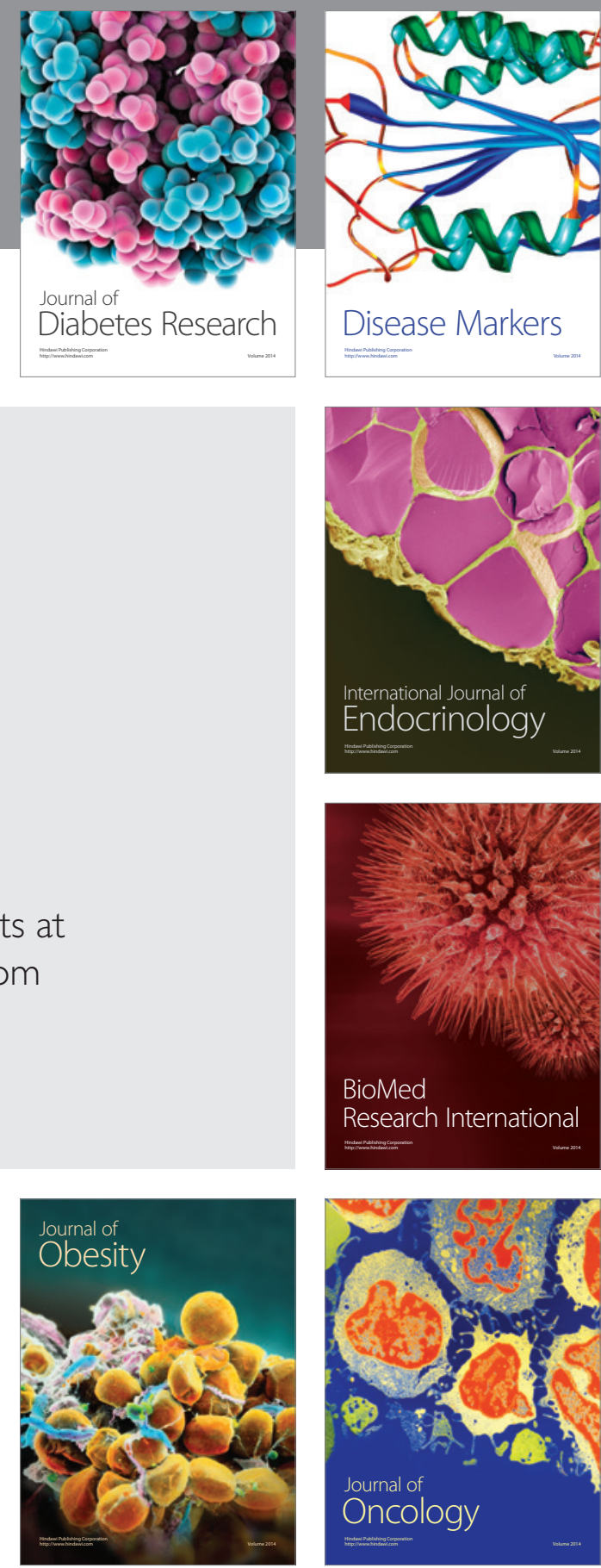

Disease Markers
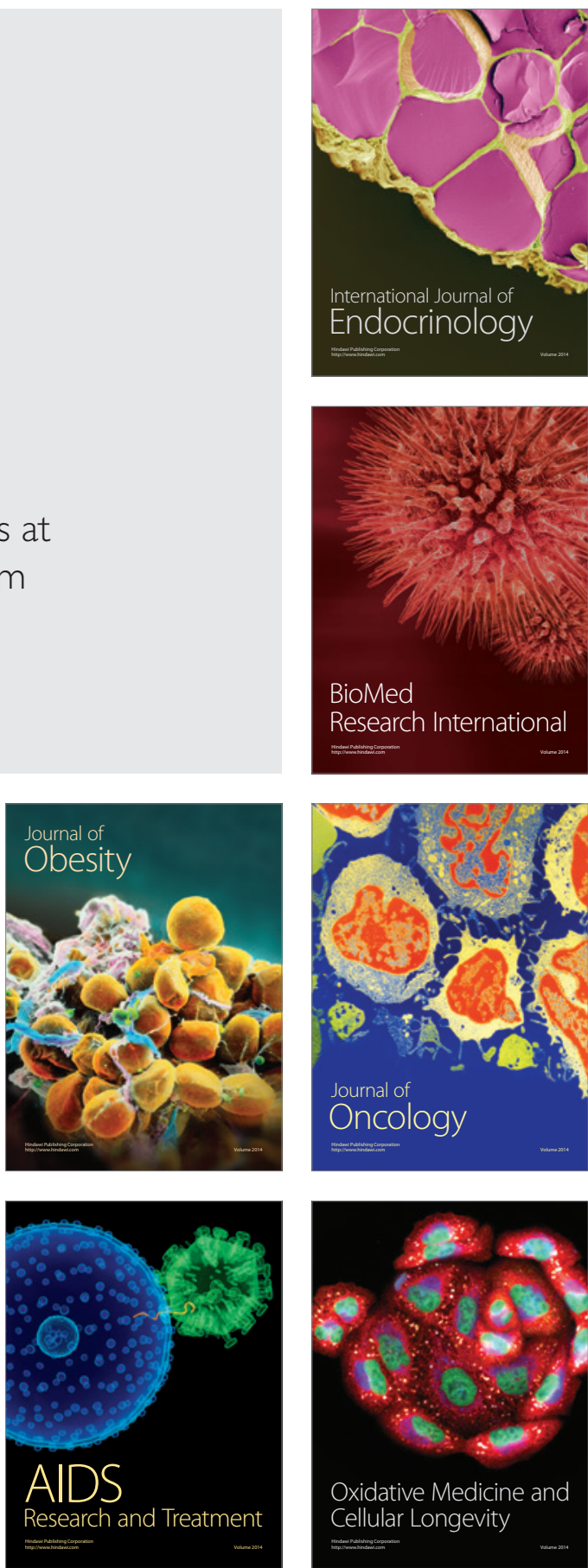